\title{
Heavy metal contamination in canned fish marketed in Ghana
}

\author{
N.O. Boadi, S.K.Twumasi, M. Badu and I. Osei \\ Department of Chemistry, Kwame Nkrumah University of Science and Technology, Kumasi. \\ Ghana
}

\begin{abstract}
The concentrations of $\mathrm{Pb}, \mathrm{Zn}, \mathrm{Fe}, \mathrm{Cd}, \mathrm{Mn}$ and $\mathrm{Hg}$ in 46 canned fish samples of nine different brands purchased within Kumasi in the Ashanti Region of Ghana were determined using the Flame Atomic Absorption Spectrophotometer for $\mathrm{Pb}, \mathrm{Zn}, \mathrm{Fe}, \mathrm{Cd}$ and $\mathrm{Mn}$ and direct mercury analyzer (DMA) for $\mathrm{Hg}$. The ranges obtained for the elements analyzed in $\mu \mathrm{g} / \mathrm{g}$ (wet weight) are as follows: $\mathrm{Pb}(0.058-0.168)$, Zn (0.010 - 0.370), $\mathrm{Hg}(0.088$ - 0.410), Mn (0.001 - 0.057), Fe(0.990 - 32.607) and Cd, below detection limit in all the samples. The fish samples had $\mathrm{Hg}$ levels below the European dietary limit of $0.5 \mu \mathrm{g} / \mathrm{g}$. Zinc levels were generally below the Food and Agriculture Organization (FAO) recommended limit of $40 \mu \mathrm{g} / \mathrm{g}$. The concentration of lead in the canned fish was also below the MAFF guidelines of $2.0 \mu \mathrm{g} / \mathrm{g}$. Also, based on the United States Environmental Protection Agency (US EPA) health criteria for carcinogens, there are no health risks associated with $\mathrm{Pb}$ concentrations in canned fishes analyzed. The result of the one-way analysis of variance (ANOVA) conducted on the data suggested no significant variations $(P>0: 05)$ in the concentrations of the metals in the same brands of canned fishes.
\end{abstract}

Keywords: canned fish, dietary intake, heavy metals, Kumasi, A.A.S, D.M.A.

\section{INTRODUCTION}

The toxic nonessential metals - cadmium, mercury, and lead are characterized as having no demonstrated biological requirement in humans, and exposure is associated with recognizable toxicity. Also, severity of toxicity increases with increases in dosage. Although there may be some lower limit of exposure at which toxicity may not be detected (threshold), there may be no level at the molecular level that does not have an adverse effect (Goyer, 1994).

Fish is widely consumed in many parts of the world by humans because it has high protein content, low saturated fat and also contains omega 3 fatty acids known to support good health (US EPA, 2004). Fish is a major source of iron for adults and children. Iron deficiency causes anemia (Institute of Medicine, 2003). The consumption of canned fishes in particular is widespread in the developed world especially in United States of America because it is convenient and affordable for most working families. The latest data from the FAO show that the United States ranks as the third largest consumer of seafood in the world, importing $76 \%$ of its seafood (NOAA, 2002). For example, canned tuna is consumed by about $90 \%$ of American households and accounts for around $20 \%$ of US seafood consumption. Children eat more than twice as much tuna as any other fish, and canned tuna is also the most frequently consumed fish among women of childbearing age (Mercury Policy Project, 2003). Fish may be contaminated by toxic elements during fish growth, transportation, and storage. Contamination may also occur during production handling and canning process.

Lead poisoning is generally ranked as the most common environmental health hazard (Goyer, 1994). Apart from threat from polluted environment, canned fish is subjected to lead contamination during canning process. Solder used in manufacture of cans has been recognized as a source of lead contamination during canning (MAFF, 1995).

The toxic effects of heavy metals particularly mercury, cadmium and lead have been broadly studied (Uchida et al., 1961; Schroeder, 1965; Venugopal and Luckey, 1975; Inskip \& Piotrowsiki., 1985; Nishihara et al., 1985; Kurieshy \& D'siliva., 1993; Narvaes, 2002). Levels of heavy metals in fish have been widely reported (Winchester, 1988; Kowalewska \& Korzeniewski, 1991; Sharif et al., 1991; Hossain et al., 1993; Joseph \& Srivastava, 1993).

Metal contaminations in food, especially in marine products has also been broadly investigated (Enomoto \& Uchida, 1973; Glover, 1979; Uysal, 
1980; Uysal, 1990; Liang et al., 1999; Catsiki \& Strogyloudi, 1999). High lead (Edwards et al., 2001) concentrations in fish have also been reported.

The WHO has adopted the US EPA levels for mercury and recommends that food with concentrations of $0.5 \mathrm{mg} / \mathrm{kg}$ or more should not be sold for human consumption. In Japan, because of the high consumption of fish, the government has recommended that fish with mercury level of $0.3 \mathrm{mg} / \mathrm{kg}$ (wet weight) or over should not be sold (Dickman and Leung, 1998). The US FDA currently stipulated an action level of $1.0 \mathrm{mg} / \mathrm{kg}$ for methyl mercury in the edible portion of fish pending when all new data are evaluated (FDA, 2000).

Publications on the concentrations of trace elements in processed or canned fishes and dietary intakes of toxic elements from canned fishes in Ghana are limited.

Information on the metal content in canned fish is important to ensure that the fish consumed is safe for human consumption. This study reports the concentrations of heavy metals in canned fish samples purchased from food outlets in the Ashanti region of Ghana.

\section{MATERIALS AND METHODS}

Apparatus: All glassware were soaked overnight in $10 \%(\mathrm{v} / \mathrm{v})$ nitric acid, followed by washing with $10 \%$ $(\mathrm{v} / \mathrm{v})$ hydrochloric acid, and rinsed with double distilled water and dried before using. Determination of mercury in all the digests was carried out by cold vapour atomic absorption spectrophotometer using an automatic Mercury Analyzer Model HG-5000 (Sanso Seisakusho co., Ltd, Japan) developed at NIMD.

A UNICAM Model 929 flame atomic absorption spectrophotometer equipped with a deuterium background corrector was used for the determination of lead, cadmium, zinc, manganese and iron.

Reagents: All reagents used were of analytical reagent grade. Standard stock solutions of mercury, cadmium, lead, zinc, manganese and iron were prepared from Titrasol (1000 mg/l) (Merck, Germany) and were diluted to the desired concentrations for the corresponding metals. The acids used were purchased from BDH, England. The working solutions were freshly prepared by diluting an appropriate aliquot of the stock solutions using $10 \%$ $\mathrm{HNO}_{3}$ for diluting lead and cadmium solutions, $1 \mathrm{M}$ $\mathrm{HCl}$ and $5 \% \mathrm{H}_{2} \mathrm{SO}_{4}$ for diluting mercury solution. Stannous chloride, for mercury analysis, was freshly prepared by dissolving $10 \mathrm{~g}$ in $100 \mathrm{ml}$ of $6 \mathrm{M} \mathrm{HCl}$. The solution was boiled for about $5 \mathrm{~min}$, cooled, and nitrogen bubbled through it to expel any impurities.

Sample preparation and Digestion: Nine different brands of forty six canned fishes (about $0.5 \mathrm{~kg}$ each) and their sauces were used for this study. They are labeled $A_{1}(n=5), A_{2}(n=5), B S(n=7), S M(n=5)$, LS $(n=6), \operatorname{VP}(n=5), G M(n=6), P S(n=4)$ and TS $(n=3)$. After opening, each can content was homogenized thoroughly in a food blender with stainless steel cutters. A sample was then taken and digested promptly as follows: the homogenized sample $(2 \pm 0.001 \mathrm{~g})$ was weighed into a $0.5 \mathrm{~L}$ glass digestion tube, and for mercury, $10 \mathrm{ml}$ of conc. $\mathrm{HNO}_{3} /$ $\mathrm{HClO}_{4}$ at a ratio of $1: 1$ and $5 \mathrm{ml}$ of conc. $\mathrm{H}_{2} \mathrm{SO}_{4}$ were slowly added. The tube was then placed on top of a steam bath unit to complete dissolution. It was then removed from the steam bath, cooled and the solution transferred carefully into a $50 \mathrm{ml}$ volumetric flask.

For the determination of lead, cadmium, zinc, manganese and iron, about $2 \pm 0.001 \mathrm{~g}$ of homogenized sample was weighed into a $200 \mathrm{ml}$ beaker and $10 \mathrm{ml}$ of conc. $\mathrm{HNO}_{3} /$ was added. The beaker was covered with a watch glass and, after most of the sample had dissolved by standing overnight, heated on a hot plate with boiling until any vigorous reaction had subsided and a clear solution obtained. The solution was allowed to cool, transferred into a $50 \mathrm{ml}$ volumetric flask and diluted to the mark with distilled water.

Chemical analysis: Mercury was determined by Cold Vapor Atomic Absorption Spectrophotometer using the Direct Mercury Analyzer. Lead, cadmium, zinc, manganese and iron, were determined using UNICAM 969 Flame Atomic Absorption Spectrometer. The detection limits in $\mu \mathrm{g} / \mathrm{ml}$ for the metals are 0.010 for lead, 0.001 for cadmium, 0.002 for zinc, 0.002 for manganese, 0.005 for iron and 0.001 for mercury.

Quality assurance: The accuracy of the analytical procedure was checked by duplication of the samples and analytical validation was conducted through the analysis of certified reference samples (DORM-2) for mercury and other metals. Method blanks were conducted for all metal determinations in fish samples. The blanks for the elements determined on Flame A.A.S were prepared by following the analytical steps in the analysis method without a sample. Prior to the mercury determinations in fish samples, the mercury levels were first determined by 
analyzing them as blanks under the same experimental condition used to analyze the samples. DORM-2 standards were analyzed in between ten sample runs and then followed by the analysis of blank boats prior to commencement of more sample runs.

Statistical Methods: The descriptive statistics (mean and range) and one-way analysis of variance (ANOVA) were conducted using excel software. A one-way ANOVA statistical procedure was employed in the assessment of variation in metal concentrations among canned fish of the same brand and across canned fish of different brands.

\section{RESULTS AND DISCUSSION}

Table 1 shows the measured values obtained from the analyses of DORM-2. The data obtained from the analyses of the standards show a strong agreement with the certified reference values provided by the NRC of Canada.

Table 1. Validation of Flame A.A.S and DMA with certified reference material (DORM-2)

\begin{tabular}{|l|l|l|}
\hline \multirow{2}{*}{ Element } & \multicolumn{2}{|l|}{ DORM-2 (dogfish muscle) } \\
\cline { 2 - 3 } & $\begin{array}{l}\text { Certified } \\
\text { value(mg/kg) }\end{array}$ & $\begin{array}{l}\text { Measured value } \\
\text { (mg/kg) }\end{array}$ \\
\hline $\mathrm{Pb}$ & $0.065 \pm 0.007$ & $0.062 \pm 0.004$ \\
\hline $\mathrm{Zn}$ & $25.6 \pm 2.3$ & $25.8 \pm 0.23$ \\
\hline $\mathrm{Fe}$ & $142 \pm 10$ & $143 \pm 2.23$ \\
\hline $\mathrm{Mn}$ & $3.66 \pm 0.34$ & $3.62 \pm 0.12$ \\
\hline $\mathrm{Hg}$ & $4.64 \pm 0.26$ & $4.32 \pm 0.05$ \\
\hline
\end{tabular}

The concentrations of lead, zinc, iron, manganese, cadmium and mercury, are presented in Table 2 below with means and ranges. The results indicate that $\mathrm{Pb}$ concentration in canned fish ranged from $0.058-0.168 \mu \mathrm{g} / \mathrm{g}$ whereas $\mathrm{Zn}$ concentration ranged from $0.010-0.370 \mu \mathrm{g} / \mathrm{g}$ and below detection limits for $\mathrm{Cd}$ in the canned fish. Levels of $\mathrm{Hg}$ in canned fish ranged from $0.088-0.410 \mu \mathrm{g} / \mathrm{g}$. Fe concentration in the canned fish ranged from $0.990-32.607 \mu \mathrm{g} / \mathrm{g}$ while $\mathrm{Mn}$ concentration in the canned fish ranged from $0.001-0.057 \mu \mathrm{g} / \mathrm{g}$. Statistical analysis of the concentrations of each heavy metal by ANOVA showed no significant differences within the samples of the same brand $\mathrm{P}>0.05$.

The levels of toxic elements in fish are related to age, sex, season and place (Kagi \& Schaffer, 1998). It is also reported that cooking reduces the amount of some metals (Atta et al., 1997) whereas the concentration of mercury in fish cannot be reduced by cooking.
The concentration of mercury, cadmium, and lead in canned fish from the Mediterranean coast are of the ranges $0.02-6.60,0.09-0.32$ and $0.04-0.18 \mu \mathrm{g} / \mathrm{g}$ respectively (Voegborlo, El-Methnani, \& Abedin, 1999) and work done in lakes in Tokat, Turkey by Mendil et al., (2005) gave levels of zinc, iron, and lead respectively as $48.6 \mu \mathrm{g} / \mathrm{g}, 167 \mu \mathrm{g} / \mathrm{g}$, and 2.8 $\mu \mathrm{g} / \mathrm{g}$. Other surveys by the committee for inland Fisheries of Africa, (CIFA) showed that cadmium levels in several fish types caught in upper Australia waters were $0.10-0.13$ and $0.050-0.97 \mu \mathrm{g} / \mathrm{g}$ (CIFA, 1992). Tuzen and Soylak (2007) reported levels of zinc, iron, lead and cadmium in canned fish marketed in Turkey in the ranges of $0.90-2.50 \mu \mathrm{g} / \mathrm{g}$, $10.2-30.3 \mu \mathrm{g} / \mathrm{g}, 0.09-0.40 \mu \mathrm{g} / \mathrm{g}$ and $0.06-0.25 \mu \mathrm{g} / \mathrm{g}$ respectively. The levels of cadmium obtained in our work were lower than the US-EPA recommended limit of $0.20 \mu \mathrm{g} / \mathrm{g}$. The concentration of lead in all the samples was lower than US-EPA recommended limit of $4.0 \mu \mathrm{g} / \mathrm{g}$. The concentration of mercury in this study, $0.088-0.410 \mu \mathrm{g} / \mathrm{g}$, is lower than that reported in canned fish $0.82-1.2 \mu \mathrm{g} / \mathrm{g}$ by Holden (1973) and comparable with $0.04-0.44 \mu \mathrm{g} / \mathrm{g}$ by Fricke et al, (1979). The metal content in canned tuna fish reported by Khansari et al (2005) varied from 0.0430 -0.253 for mercury, $0.0046-0.0720$ for cadmium and from $0.0162-0.0726$ for lead.

The concentration of mercury, cadmium and lead in canned fish previously reported by FDA (2000) were $0.082-0.160,0.006-0.088$ and $0.016-0.049 \mu \mathrm{g} / \mathrm{g}$ respectively. These results are similar to what was obtained in this research except for lead and mercury which were lower than the results obtained in our work.

The variation of metal concentration in the different canned fish analyzed could be attributed to the fact that some fish are older in age than others. The level of contaminants in fish is influenced by the duration of exposure of fish to contaminants in water, feeding habit of fish, concentrations of contaminants in water column, water chemistry, contamination of fish during handling and processing, quality of canned fish and shelf life of canned fish. According to Taha' n, et al. (1995), the $\mathrm{pH}$ of the canned product, the quality of the lacquer coatings of canned products, oxygen concentration in the headspace, quality of coating and storage place may also control metal levels in canned fishes. The results obtained for manganese in canned fish studied was comparable with the results obtained by Ikem and Egiebor (2005) which ranged from $0.01-2.55 \mu \mathrm{g} / \mathrm{g}$ and lower than the 
corresponding maximum level reported for canned sardines in Brazil (15.77 $\mu \mathrm{g} / \mathrm{g}$ : Tarley et al., 2001).

Table2: Concentration of heavy metals in canned fish (mean and range)

\begin{tabular}{|c|c|c|c|c|c|c|c|}
\hline $\begin{array}{l}\text { Sample } \\
\text { (Fish and } \\
\text { Type) }\end{array}$ & $\mathbf{n}$ & $\begin{array}{c}\mathrm{Pb} \\
(\mu \mathrm{g} / \mathrm{g})\end{array}$ & $(\mu g / g)$ & $\begin{array}{c}\mathrm{Fe} \\
(\mu \mathrm{g} / \mathrm{g})\end{array}$ & $\begin{array}{c}\text { Cd } \\
(\mu g / g)\end{array}$ & $\begin{array}{c}\mathrm{Mn} \\
(\mu \mathrm{g} / \mathrm{g})\end{array}$ & $\underset{(\mu \mathrm{g} / \mathrm{g})}{\mathrm{Hg}}$ \\
\hline $\begin{array}{c}\mathrm{AQ}_{1} \\
\text { (mackerel) }\end{array}$ & 5 & $\begin{array}{c}0.140 \\
(0.132-0.154)\end{array}$ & $\begin{array}{c}0.171 \\
(0.168-0.185)\end{array}$ & $\begin{array}{c}1.930 \\
(1.720-2.100)\end{array}$ & $<0.001$ & $\begin{array}{c}0.018 \\
(0.017-0.019)\end{array}$ & $\begin{array}{c}0.102 \\
(0.093-0.105)\end{array}$ \\
\hline $\begin{array}{c}\mathrm{AQ}_{2} \\
\text { (mackerel) }\end{array}$ & 5 & $\begin{array}{c}0.165 \\
(0.163-0.168)\end{array}$ & $\begin{array}{c}0.068 \\
(0.066-0.072)\end{array}$ & $\begin{array}{c}1.185 \\
(1.135-1.400)\end{array}$ & $<0.001$ & $\begin{array}{c}0.008 \\
(0.006-0.011)\end{array}$ & $\begin{array}{c}0.128 \\
(0.127-0.130)\end{array}$ \\
\hline $\begin{array}{c}\text { BS } \\
\text { (sardine) }\end{array}$ & 7 & $\begin{array}{c}0.099 \\
(0.058-0.152)\end{array}$ & $\begin{array}{c}0.136 \\
(0.040-0.158)\end{array}$ & $\begin{array}{c}9.230 \\
(8.330-10.200)\end{array}$ & $<0.001$ & $\begin{array}{c}0.035 \\
(0.020-0.041)\end{array}$ & $\begin{array}{c}0.128 \\
(0.120-0.145)\end{array}$ \\
\hline $\begin{array}{c}\mathrm{SM} \\
\text { (mackerel) }\end{array}$ & 5 & $\begin{array}{c}0.125 \\
(0.091-0.144)\end{array}$ & $\begin{array}{c}0.143 \\
(0.126-0.175)\end{array}$ & $\begin{array}{c}15.100 \\
(10.400-17.200)\end{array}$ & $<0.001$ & $\begin{array}{c}0.036 \\
(0.033-0.044)\end{array}$ & $\begin{array}{c}0.135 \\
(0.088-0.163)\end{array}$ \\
\hline $\begin{array}{c}\text { LS } \\
\text { (sardine) }\end{array}$ & 6 & $\begin{array}{c}0.155 \\
(0.144-0.158)\end{array}$ & $\begin{array}{c}0.155 \\
(0.106-0.193)\end{array}$ & $\begin{array}{c}21.300 \\
(14.215-32.607)\end{array}$ & $<0.001$ & $\begin{array}{c}0.020 \\
(0.008-0.025)\end{array}$ & $\begin{array}{c}0.143 \\
(0.140-0.146)\end{array}$ \\
\hline $\begin{array}{c}\text { VP } \\
\text { (pilchard) }\end{array}$ & 5 & $\begin{array}{c}0.136 \\
(0.127-0.141)\end{array}$ & $\begin{array}{c}0.193 \\
(0.010-0.365)\end{array}$ & $\begin{array}{c}11.480 \\
(10.110-16.320)\end{array}$ & $<0.001$ & $\begin{array}{c}0.019 \\
(0.011-0.041)\end{array}$ & $\begin{array}{c}0.400 \\
(0.399-0.410)\end{array}$ \\
\hline $\begin{array}{c}\text { GM } \\
\text { (mackerel) }\end{array}$ & 6 & $\begin{array}{c}0.136 \\
(0.128-0.141)\end{array}$ & $\begin{array}{c}0.166 \\
(0.043-0.370)\end{array}$ & $\begin{array}{c}10.900 \\
(10.130-12.204)\end{array}$ & $<0.001$ & $\begin{array}{c}0.006 \\
(0.001-0.013)\end{array}$ & $\begin{array}{c}0.140 \\
(0.135-0.142)\end{array}$ \\
\hline $\begin{array}{c}\text { PS } \\
\text { (sardine) }\end{array}$ & 4 & $\begin{array}{c}0.156 \\
(0.152-0.163)\end{array}$ & $\begin{array}{c}0.179 \\
(0.138-0.217)\end{array}$ & $\begin{array}{c}21.450 \\
(14.210-32.550)\end{array}$ & $<0.001$ & $\begin{array}{c}0.036 \\
(0.022-0.057)\end{array}$ & $\begin{array}{c}0.141 \\
(0.140-0.141)\end{array}$ \\
\hline $\begin{array}{c}\text { TS } \\
\text { (sardine) }\end{array}$ & 3 & $\begin{array}{c}0.087 \\
(0.086-0.088)\end{array}$ & $\begin{array}{c}0.088 \\
(0.086-0.090)\end{array}$ & $\begin{array}{c}1.063 \\
(0.990-1.200)\end{array}$ & $<0.001$ & $\begin{array}{c}0.006 \\
(0.005-0.007)\end{array}$ & $\begin{array}{c}0.117 \\
(0.110-0.120)\end{array}$ \\
\hline
\end{tabular}

United States National Research Council has recommended safe and adequate daily intake levels for manganese that range from 0.3 to $1 \mathrm{mg} /$ day for children up to 1 year, $1-2 \mathrm{mg} /$ day for children up to age 10, and 2-5 mg/day for children 10 and older (Institute of Medicine, 2003). Daily intake of small amounts of manganese is needed for growth and good health in children. Children, as well as adults, who lose the ability to remove excess manganese from their bodies, develop nervous system problems. According to the EPA, there is no information on the carcinogenicity of manganese (Agency for Toxic Substances and Disease Registry, 2004).

The Range for iron in muscles of sardines (Canli and Atli, 2003) in $\mu \mathrm{g} / \mathrm{g}$ was $39.607 \pm 8.62$. The results were comparable with some of the concentrations obtained in this work.

Significant variation in the concentrations of lead, mercury, iron, manganese and zinc existed across the various fish species and canned fish brands $(P<0: 05)$. However, there were no significant variations $(P>0.05)$ of these metals in the same species. There was also no significant variation for cadmium across the various fish species and canned fish brands.

\section{CONCLUSION}

The metal contents in canned fish, expressed in $\mu \mathrm{g} / \mathrm{g}$ wet weight, varied from $0.058-0.168$ for lead, from $0.010-0.370$ for zinc, from $0.088-0.410$ for mercury, from 0.001 - 0.057 for manganese, from 0.990 32.607 for iron, and below detection limit for cadmium. The results from this study suggested that significant differences existed in the element concentrations across nine different canned fish brands. Also, analytical data obtained from this study shows that the metal concentrations for the varieties of canned fishes were generally within the WHO/FAO, FDA and US. EPA recommended limits for fish. There is therefore no serious health risk associated with the consumption of canned fishes analyzed. Both low-risk groups (adolescents and adults) and high-risk groups (pregnant mothers and children) must, based on the results obtained, reduce the consumption of canned fish as frequent 
consumption may result in bioaccumulation of the metals and increased health risks. Globally, further reduction in the levels of environmental contaminants emanating from power plants and other industrial emissions and effluent discharges are highly needed to reduce contaminant inputs into the aquatic environment. More research and assessments of seafood quality is needed in many countries to provide more data and help safeguard the health of humans.

\section{ACKNOWLEDGEMENT}

The authors would like to thank all persons who in immeasurable ways contributed to the success of the research and to the Chemistry Department, Kwame Nkrumah University of Science and Technology, Kumasi for their financial support.

\section{REFERENCES}

Agency for Toxic Substances and Disease Registry, (2004). Agency for Toxic Substances and Disease Registry, Division of Toxicology, Clifton Road, NE, Atlanta, GA. Available at: http://www.atsdr.cdc.gov/toxprofiles/.

Atta, M. B., El-Sebaie, L. A., Noaman,M. A., and Kassab, H. E. (1997). The effect of cooking on the content of heavy metals in fish. Food Chemistry, 58, 1-4.

Canli, M., Atli, G. (2003). The relationships between heavy metal ( $\mathrm{Cd}, \mathrm{Cr}, \mathrm{Cu}, \mathrm{Fe}, \mathrm{Pb}, \mathrm{Zn}$ ) levels and the size of six Mediterranean fish species. Environmental Pollution 121, 129-136.

Catsiki, V. A., \& Strogyloudi, E. (1999). Survey of metal levels in common fish species from Greek waters. The Science of the Total Environment, 237/238, 387-400.

CIFA. (1992). Committee for Inland Fisheries of Africa. Report of the third session of the working party on pollution and fisheries. FAO Fisheries Report No. 471. Food and Agriculture Organization of the United Nations, Rome.

Dickman, M.D., Leung, K.M.C. (1998). Mercury and organochlorine exposure from fish consumption in Hong Kong. Chemosphere 37, 991-1015.

Edwards, J.W., Edyvane, K.S., Boxall, V.A., Hamann, M., Soole, K.L. (2001). Metal levels in Seston and marine fish flesh near industrial and metropolitan centres in South Australia. Marine Pollution Bulletin 42, 389-396.

Enomoto, N., \& Uchida, Y. (1973). Cadmium and other heavy metals contents in marine products from Ariak sea in canned goods on the market. Saga daigaku Nogaku Inho, 69-75, [cited in Chem. Abstr 18 (1974) 2506].
FDA. (2000). Total diet study statistics on element results. Washington, DC: US Food and drug administration.

Fricke, F. L., Robbins, W. B., \& Caruso, A. (1979). Trace elementanalysis of food and beverages by atomic absorption spectrophorometery. Progress in Analytical Atomic Spectroscopy, 2, 185-286.

Glover, J. W. (1979). Concentration of arsenic, selenium and ten heavy metals in school shark, Galeorhinus australia (Macleay) and gumney shark, Mustelus antarcticus cunther, from south eastern Australian waters. Australian Journal of Marine Fresh Water Research, 30, 505.

Goyer R.A. (1994). Biology and nutrition of essential elements. In Risk Assessment of Essential Elements, ed. W Mertz, CO Abernathy, SS Olin, pp. 13-19. Washington, DC: Int. Life Sci. Inst. 300 pp.

Holden, A. V. (1973). Mercury in fish and shellfish, a review. Journal of Food Technology, 8, 1-25.

Hossain M.A., Sharif A.K.M., Mustafa A.I and Amin M.N.(1993). Trace element concentrations in ten species of freshwater fish of Bangladesh. The Science of the Total Environment, 138 (1-3), 117-126

Ikem, A., Egiebor, N.O., (2005). Assessment of trace metal elements in canned fishes( Mackerel, tuna, salmon, sardines, and herrings) marketed in Geaorgia and Alabama (United States of America). J. Food Composition and Analysis. 18, 771-787

Inskip, M. J., \& Piotrowsiki, J. K. (1985). Review of the health effects of methyl mercury. Journal of Applied Toxicology, 5, 113-133.

Institute of Medicine, (2003). Dietary Reference Intakes: Applications in Dietary Planning. Subcommittee on Interpretation and Uses of Dietary Reference Intakes and the Standing Committee on the Scientific Evaluation of Dietary Reference Intakes. Institute of Medicine of the National Academies, The National Academies Press, Washington, DC, p. 248.

Joseph, K. O., \& Srivastava, J. P. (1993). Mercury in the Ennore estuary and in fish from Madras coastal waters. Journal of Environmental Biology, 14, 55-62.

Kagi, J. H., \& Schaffer, A. (1998). Biochemistry of metallothionein. Biochemistry, 27, 8509-8515.

Khansari, F.E., Ghazi- Khansari, M., Abdollahi, M. (2005). Heavy metals content in canned Tuna fish. Food Chem. 93, 293-296

Kowalewska, M., \& Korzeniewki, K. (1991). Trace metals in Gasterosteus aculeatus L. from the Gdansk Bay. Pol. Arch. Hydrobiology. 38, 475-484.

Kurieshy, T. W., \& D_siliva, C. (1993). Uptake and loss of mercury, cadmium and lead in marine organisms. Indian Journal of Experimental Biology, 31, 373-379. 
Liang, Y., Cheung, R. Y. H., \& Wong, M. H. (1999). Reclamation of wastewater for polyculture of freshwater of freshwater fish, bioaccumolation of trace metals in fish. Water Research, 33, 2690-2700.

MAFF, (1995). Monitoring and surveillance of nonradioactive contaminants in the aquatic environment and activities regulating the disposal of wastes at sea, 1993. Aquatic Environment Monitoring Report No. 44. Directorate of Fisheries Research, Lowestoft.

Mendil, D., Uluözlü, Ö.D., Hasdemir, E., Tüzen, M., Sari, H., Suiçmez, M. (2005). Determination of trace metal levels in seven fish species in lakes in Tokat, Turkey. Food Chemistry, 90(1-2), 175-179

Mercury Policy Project (2003). 1420 North Street, Montpelier, VT, USA, available at: http://www.mercurypolicy.org/new/documents/CanThe Tuna061903.pdf.

Narvaes, D. M. (2002). Human exposure to mercury in fish in mining areas in the Philippines. FAO/WHO Global forum of food safety regulation. Morocco: Marrakec.

Nishihara, T., Shimamato, T., Wen, K. C., \& Kondo, M. (1985). Accumulation of lead, cadmium and chromium in several organs and tissues of carp. Journal Hygienic Chemistry, 31, 119-123.

NOAA (National Oceanic and Atmospheric Administration), (2002). Shrimp overtakes canned tuna as top US seafood-overall seafood consumption decreases in 2001. NOAA 2002-113, available at: http://www.publicaffairs.noaa.gov/releases2002/aug02/ noaa02113.html

Schoerder, H. A. (1965). Cadmium as a factor in hypertension. Journal of Chronic Diseases, 18, 647.

Sharif, A. K. M., Mustafa, A. L., Mirza, A. H., \& Safiullah, S. (1991). Trace metals in tropical marine fish from the Bay of Bengal. Science of the Total Environment, 107, 135-142.

Taha' n, J.E., Sanchez, J.M., Granadillo, V.A., Cubillan, H.S., Romero, R.A.(1995). Concentration of total Al, $\mathrm{Cr}, \mathrm{Cu}, \mathrm{Fe}, \mathrm{Hg}, \mathrm{Na}, \mathrm{Pb}$, and $\mathrm{Zn}$ in commercial canned seafood determined by atomic spectrometric means after mineralization by microwave heating. Journal of Agricultural and Food Chemistry 43, 910-915.

Tarley, C.R.T., Coltro, W.K.T., Matsushita, M., de Souza, N.E. (2001). Characteristic levels of some heavy metals from Brazilian canned sardines (Sardinella brasiliensis). Journal of Food Composition and Analysis 14, 611-617.

Tuzen, M., Soylak, M., Determination of trace metals in canned fish marketed in Turkey. Food Chemistry 101 (4) 1395-1399.

Uchida, M., Hirakawa, Y., \& Inoue, T. (1961). Biochemical studies on Minamata disease IV. Isolation and chemical identification of the mercury compound in the toxic shellfish with special references to the causal agent of the disease. Kumamoto Medial Journal, 14, 182-218.

US EPA (2004). What you need to know about mercury in fish and shellfish. EPA-823-F-04-009, 2pp, available at:

http://www.epa.gov/waterscience/fish/MethylmercuryBr ochure.pdf

Uysal, H. (1980). Levels of trace elements in some food chain organisms from the Aegean Coasts. Journess Etudes Pollution, 503- 512.

Uysal, H. (1990). Heavy metal concentrations in selected species from fisheries bay of Aegean Coast. Rapport Commission International Mer Mediterrane' e, 33, 187.

Venugopal, B., \& Luckey, T. (1975). Toxicity of non radioactive heavy metals and their salts. In F. Coulston (Ed.), Heavy metal toxicity, safety and hormology. New York: Academic press, George Thieme Stuttagart

Voegborlo, R.B., El-Methnani, A.M., Abedin, M.Z. (1999). Mercury, cadmium and lead content of canned tuna fish. Food Chemistry 67, 341-345.

Winchester, R. V. (1988). Trace metal levels in fish from the Manukau Habour, Auckland, New Zealand, related to a water pollution incident. New Zealand Journal of Marine Freshwater Research, $22.621-624$. 